\title{
Paradoxical Pain from Opioids: Increased Risk of Acute Pancreatitis
}

\author{
Vijay P. Singh ${ }^{1}$
}

Published online: 31 October 2019

(c) Springer Science+Business Media, LLC, part of Springer Nature 2019

Opioids have an intimate relationship with pancreatitis. This class of drugs is commonly used for pain control for acute and chronic pancreatitis, but it has been speculated that opioids may also cause acute pancreatitis. There are several case reports associating the use of opioids with an attack of acute pancreatitis [1-3], and opium addicts may have a dilated bile or pancreatic duct [4], which has been attributed to sphincter of Oddi dysfunction. This has been thought to result from increased phasic amplitude and frequency of sphincter contractions mediated by mu opioid receptors $[5$, $6]$ that in turn may contribute toward the development of pancreatitis in the possum [7]. The increased risk of pancreatitis reported with eluxadoline (Viberzi), which is a mu receptor agonist [8], may also relate to this mechanism.

In this issue of Digestive Diseases and Sciences, Kim et al. [9] highlighted the increased risk of AP with the use of opiates. The authors performed a retrospective nested case-control study of a commercial claims database for patients who underwent cholecystectomy between 2005 and 2014. Starting 12 months after cholecystectomy, they follow 664,083 patients, identifying 1707 who developed pancreatitis after appropriate exclusions. The use of codeine and other relevant drugs and comorbidities are compared between these patients and 17,063 $(10 \times)$ matched controls. They note $22(1.3 \%)$ of the patients vs. $80(0.5 \%)$ of the controls used codeine with an adjusted odds ratio of 2.67 (CI 1.63-4.36) for developing acute pancreatitis, which is higher than with NSAID use. Nonetheless, the need for a comparison with NSAIDs, which is a major theme of the study, is questionable, especially since NSAIDs may protect from post-ERCP pancreatitis [10].

Although cholecystectomy is assumed to reduce the risk of acute pancreatitis, the authors note a 1.1 per 1000 personyear risk of pancreatitis, which is $\sim 2-3$ times higher than

Vijay P. Singh

singh.vijay@mayo.edu

1 Division of Gastroenterology and Hepatology, Department of Medicine, Mayo Clinic, Scottsdale, AZ 85259, USA the incidence noted in previous studies from the USA [11]. The authors attribute the increased risk of acute pancreatitis to sphincter of Oddi dysfunction. Here it is important to realize a major limitation that they partly acknowledge, which is that other important causes of pancreatitis such as undocumented alcoholism, common bile duct stones, and undiagnosed idiopathic pancreatitis may have been missed by the study design, especially since these conditions can lead to or be associated with higher opiate use. This point is further reinforced by the lack of evidence supporting pancreatic sphincter of Oddi dysfunction as a cause of pancreatitis in this study and the strong society guidelines that recommend exclusion of other causes before attributing pancreatitis to sphincter of Oddi dysfunction [12]. Since common bile duct pressures can be elevated after cholecystectomy [13], a post hoc analysis of effect of sphincterotomy (which was excluded) on the risk of post-cholecystectomy pancreatitis may have helped. This is relevant to the hypothesis and conclusions of the study since sphincterotomy would be an antidote for sphincter of Oddi dysfunction and hypothetically should reduce the risk of AP even with narcotic use.

While the conclusions of the study that codeine use increases the risk of acute pancreatitis are valid after adjustment for confounders including comorbidities and other medications, the rationale for choosing codeine over other opiates is unclear. For example, 788 (46.3\%) of the 1707 patients who developed acute pancreatitis used non-codeine opioids such as hydrocodone, morphine, oxycodone, or tramadol in numbers much higher than the $1.3 \%$ who used codeine. This work therefore supports the need for future studies focused on whether more commonly prescribed opiates increase the risk of acute pancreatitis.

The study design does not permit analysis of the risk that can be directly attributed to opioid or codeine use. This is especially important since there was high usage of opioids (>30\%; table 1 of manuscript) in this cohort of patients, and is reinforced by the high prevalence of opioid usage nationwide during the study period. An alternate design allowing such an analysis in the same cohort would have been to 
compare the incidence of AP among those that used opiates after cholecystectomy to those who did not.

In summary, the study by Kim et al. is provocative by providing evidence that codeine-induced pancreatitis likely does exist, possibly due to sphincter of Oddi dysfunction. The study also opens the need for more systematic and larger studies in which the risk of pancreatitis from commonly used opioid agonists such oxycodone, hydrocodone, tramadol, and more recently eluxadoline can be studied while taking into account the impact of sphincterotomy on post-cholecystectomy pancreatitis.

\section{References}

1. Locher C, Lambare B, Fischer D, Labayle D. Acute pancreatitis induced by codeine-acetaminophen association: report of two cases. Gastroenterol Clin Biol. 2003;27:124-125.

2. Hastier P, Buckley MJ, Peten EP, et al. A new source of druginduced acute pancreatitis: codeine. Am J Gastroenterol. 2000;95:3295-3298.

3. Famularo G, Pozzessere C, Polchi S, De Simone C. Acute pancreatitis after morphine administration. Ital J Gastroenterol Hepatol. 1999;31:522-523.

4. Sharma SS. Sphincter of Oddi dysfunction in patients addicted to opium: an unrecognized entity. Gastrointest Endosc. 2002;55:427-430.

5. Thompson DR. Narcotic analgesic effects on the sphincter of Oddi: a review of the data and therapeutic implications in treating pancreatitis. Am J Gastroenterol. 2001;96:1266-1272.
6. Helm JF, Venu RP, Geenen JE, et al. Effects of morphine on the human sphincter of Oddi. Gut. 1988;29:1402-1407.

7. Chen JW, Thomas A, Woods CM, et al. Sphincter of Oddi dysfunction produces acute pancreatitis in the possum. Gut. 2000;47:539-545.

8. Fujita W, Gomes I, Dove LS, et al. Molecular characterization of eluxadoline as a potential ligand targeting mu-delta opioid receptor heteromers. Biochem Pharmacol. 2014;92:448-456.

9. Kim J, Tabner AJ, Johnson GD, Brumback BA, Hartzema A. Increased risk of acute pancreatitis with codeine use in patients with a history of cholecystectomy. Dig Dis Sci. (Epub ahead of print). https://doi.org/10.1007/s10620-019-05803-3.

10. Elmunzer BJ, Scheiman JM, Lehman GA, et al. A randomized trial of rectal indomethacin to prevent post-ERCP pancreatitis. $N$ Engl J Med. 2012;366:1414-1422.

11. Fagenholz PJ, Castillo CF, Harris NS, Pelletier AJ, Camargo CA Jr. Increasing United States hospital admissions for acute pancreatitis, 1988-2003. Ann Epidemiol. 2007;17:491-497.

12. Cotton PB, Elta GH, Carter CR, Pasricha PJ, Corazziari ES. Rome IV. Gallbladder and sphincter of Oddi disorders. Gastroenterology. 2016;150:1420-1429.

13. Gregg JA, Carr-Locke DL. Endoscopic pancreatic and biliary manometry in pancreatic, biliary, and papillary disease, and after endoscopic sphincterotomy and surgical sphincteroplasty. Gut. 1984;25:1247-1254.

Publisher's Note Springer Nature remains neutral with regard to jurisdictional claims in published maps and institutional affiliations. 